\title{
ANALYSIS OF THE IMPLEMENTATION OF ADULT EDUCATION POLICY IN SOKOTO STATE
}

\author{
UMAR, ABUBAKAR ALIYU
}

\begin{abstract}
This paper is an analysis of the implementation of adult education policy in Sokoro State. It focused mainly on finding out the effort of the Sokoto state govermment on the implementation of the Adult Education Policy/Programme with particular reference to funding, provision of instructional materials. staff velfare and problems encoumtered in the process of implementing adult education policy/programme in Sokoto State. The findings revealed that the Sokoto state government has made commendable efforts in providing transportation to the State Agency for Mass Education, for the monitoring and supenision of adult education programmes in the state. The paper also found that in the area of funding. provision of instructional materials, furniture, staff welfare and training, more effort is needed. It also revealed that the implementation of adult education programme in Sokoto state is faced with mumerous problems such as inadequate funding and lack of instructional materials. The paper recommends among other things that adequate fund and instructional materials should be provided by the government.
\end{abstract}

\section{Introduction}

According to Rashid (2002) The Nonformal education activities were started informally in Nigeria by the Christian Missionaries at different places in the $16^{\text {th }}$ century A. D. Caravan traders who penetrated Nigeria early in the $11^{\text {th }}$ century had established their presence in the major cities of the North and some satellite towns in the SouthWest. Among these traders were Islamic Scholars who served as Secretaries in the palaces of Emirs, thereby introducing Qur'anic literacy. $\mathrm{He}$ further explained that the intervention of the Islamic Clerics exposed the Northern part of the country to Arabic literacy. The Usmanu Danfodiyo's Jihad in the $18^{\text {th }}$ century resulted in a rapid expansion of the Islamic faith, which was in turn followed by an astronomical increase in the number of Qur'anic schools established. With the advent of Christian Missionaries later came the western education through which they exposed the whole of Southern Nigeria and part of Inland region to literacy.
Alao (1992) further explained that for many years, the organization and administration of Western type of Adult Education was basically under the control of the pioneering Missionaries. They organized and administered it through Churches, Societies and age groups. The organization, administration and the syllabus were not harmonized as each mission adopted any system that was considered suitable to its objective. At the time of the colonial rule in Nigeria, the colonial government at the beginning had no interest in education generally and adult education in particular. Alao (1992:28) reported that: Between 1842 when missionaries' schools started in Nigeria and 1882 when the first education ordinance was promulgated, education administration... both adult and formal was entirely in the hands of missionaries.

Alonge (1990) reported that the attitude of the then colonial government in Nigeria towards the provision of adult education in the country was economically. politically and socially detrimental to the country. 
This attitude includes the general neglect of the adult education sector and allowing the adult literacy education provision in the hands of missionaries without a clearly defined national policy and direction. Omolewa (1980) in Aderinoye (2002) asserts that the efforts being made by the Islamic and Christian Missionaries in the provision of adult education were recognized in 1925 by the British Tropical Africa, which recommended the implementation of an Adult Education Programme in the African countries. In 1930 the Colonial Government in Nigeria accepted the recommendation and in 1943 published a document on the subject. That was the beginning of the implementation of Adult Education Policy in the African countries.

Tahir (1986:9) explained that the period between 1969-1977 was characterized by efforts by the then military government to squarely address the question of education in the country. These efforts culminated into a New National Policy on Education in 1977. in which adult and non-formal education featured quite prominently. Despite all the efforts, the Sokoto State Government, (2001) reported that the $199 \mathrm{I}$ census result indicated that Sokoto State is one of the Educationally disadvantaged States in Nigeria with a high rate of out of school children and female illiteracy. While, the national literacy figure is $57 \%$, Sokoto State has $36 \%$ level of illiteracy. It is $46 \%$ for males and $27 \%$ for females. This is a very sad situation.

\section{Statement of the Problem}

Adult education has existed for a very long time als a field of sludy and practice. Before and after independence various altempts were made by both the Colonial and indigenous governments to come up with sound educational policies and programmes. For instance, the colonial government of Nigeria initiated the 1925 Education Memorandum in British Tropical Africa. The colonial government adopted a ten year Mass Literacy Campaign for the implementation and realization of its goals. The colonial government educational policy seems to be too colonial in nature and is only meant to serve their interest. After independence, agitations for a New Policy on Education was embarked by many scholars, Curriculum Organization of Nigeria and other groups including Nigerian National Council for Adult Education (NNCAE). In response to the agitations, the Military Government of Nigeria established the New National Policy on Education as recommended by the 1969 National Curriculum conference (Udoh and Akpa, 2001:45).

The New National Policy on Education has a section devoted for Mass literacy, Adult and Non formal Education as the Formal Education has in the same National Policy on Education. The aims and objectives of each form of education (formal and informal) were clearly stated. The duties and responsibilities of each tier of government (Federal, State and Local Governments) and Non-Governmental Organizations in the provision of Adult Education were clearly defined. The Federal and State Government in preparation for the implementation of the policy/programmes had set up the National Commission for Mass Literacy, Adult and Non formal Education and State Agencies for mass education respectively. The Commission and State Agencies are responsible for the implementation of the policy/programmes. In addition to 
that, State Government established Local Government Coordinating Units in order to ensure effective implementation in the rural areas.

In spite of the Nation'tal recognition of the Adult Education (Non formal Education) and its incorporation into the New National Policy on Education as well as putting in place machineries for effective implementation of the policy programmes, there seems to be a problem of large implementation gap. The Non-formal Education sector suffered serious neglect in the area of funding, staffing, training and provision of basic facilities for effective implementation of the policy when compared to the formal Education sector.

Indabawa (1991:40) asserts that since the early 1840 s an extensive schooling system have evolved, with a chain of institutions at the pre-primary, primary, secondary and tertiary levels. Not until 1997, when a "New National Policy on education, was promulgated, the Adult and non-formal education sector remained unstreamlined and generally neglected. Sadly, the changes in the sub-sector have not been farreaching as; Adult education still suffers some official maltreatment. In a similar vein Dukku (1998:227) observed that the huge capital investments made to the formal education sector of primary, secondary and tertiary was not extended to adult education considering the fact that at the time more than $50 \%$ of the adult population was not literate.

It is clearly seen from the above assertions that Adult Education subsector has a long history of neglect by the government. This neglect may perhaps be associated with the low achievement of the implementation of the policy programmes in Nigeria as a whole and Sokoto State in particular.
This paper is an analysis of implementation of Adult Education Policy in Sokoto State. It gave emphasis on finding out the effort of Sokoto State government in providing fund, instructional materials, furniture, staff welfare, training and development as well as problems militating against effective implementation of adult education in the state.

\section{Objectives of the Study}

The study was designed to find out:

1. The level of commitment of Sokoto State Government towards the realization of the objectives of the National Policy on Adult Education

2. The current problems affecting the successful implementation of Adult Education Programmes in Sokoto State.

\section{Research Questions}

The following research questions will be answered in the conduct of this study:

1. Is the Sokoto State Government actually committed to the realization of the objectives of Adult Education Policy as enshrined in the New National Policy on Education?

2. What are the problems militating against the implementation of the Adult education programmes in Sokoto State?

\section{Research Design}

The research design for this study is a descriptive survey. Nworgu (1991) asserts that descriptive survey aims at collecting datit and describing a population in a systematic manner, its 
characteristics, features or facts. Therefore. data on funding. instructional materials, transportation, furniture, staff welfare and the problems militating against effective implementation of adult education programmes in Sokoto State were collected and analyzed using descriptive method.

\section{Population of the Study}

The population of this study includes administrative officials of the Sokoto State Agency for Mass Education. Local Government Adult Education Coordinators, District Heads, Adult Education Instructors and Adult Education Learners.

\section{Sample and Sampling Techniques}

Sokoto State has twenty three (23) Local Government Areas (LGAs) which are divided into three (3) Education Zones. In view of the number of local governments and the population involved, it becomes difficult to get all of them involved in the study, as such eight (8) local Government Councils were selected "using stratified " random sampling technique. That is three (3) Local Government Councils from each of the Sokoto Central Education Zone and Eastern Education Zone. While, two (2) Local Government Councils were selected from Sokoto Western Education Zone. This gave a total of eight Local Government Councils as could be seen on table I below:

Table 1: Number of Local Government Selected for the Study

\begin{tabular}{lccc}
\hline $\begin{array}{c}\text { Educational } \\
\text { Zones }\end{array}$ & $\begin{array}{c}\text { No. of L/Govt. in } \\
\text { the zone }\end{array}$ & $\begin{array}{c}\text { \% of population } \\
\text { of L/Govt selected }\end{array}$ & $\begin{array}{c}\text { No. of L/Govt. } \\
\text { selected }\end{array}$ \\
\hline Sokoto Central & 8 & 34.78 & 3 \\
Sokoto East & 8 & 34.78 & 3 \\
Sokoto West & 7 & 30.44 & 2 \\
\hline Total & $\mathbf{2 3}$ & $\mathbf{1 0 0 \%}$ & $\mathbf{0 8}$ \\
\hline
\end{tabular}

This is to ensure that the sample is proportionately selected across all the three Educational Zones. Gay (1971) stated that stratified sampling is the process of selecting a sample in such a way that identified sub-groups in the, population are represented in sample in the same proportion that exist in the population. Out of the total population of one hundred and twenty-four thousand seven hundred and twentyone $(124,721)$, the sample size is 384 which is in accordance with Morgan and Kreycie (1971) table for determining sample size from a given population.

Equally, the sample population from the eight (s) local governments selected for the study was selected using the stratilied proportionate sampling method as suggested by Mukherjee (2000). Therefore, one hundred and fifty-five (155) samples were selected from the three LGAs selected for the study in Sokoto Central Education Zone ('SCEZ) and Sokoto Eastern Education Zone (SEEZ) will have one hundred and thirty-four (134) samples respectively. This gives a total of two hundred and eighty nine (289) samples for the six (6) LGAs while ninety five (95) samples were selected from two (2) LGAs selected for the study in Sokoto Western Education Zone (SWEZ). This brings the total sample for the study to three hundred and eighty four (384) only. Stratified sampling method was used in selecting samples from the eight LGAs selected. 


\section{Data Analysis}

Simple statistical method was employed in anilyzing both the quantitative and qualitative data supplied by the respondents. They include frequency and percentages. This is presented in tabular form.

\section{Level of Government Commitment}

Research Question 1: What is the level of commitment of Sokoto State Government to the realization of the objectives of Adult Education Policy?

This research question was answered and presented in table 2 .

Table 1: Level of Commitment of Sokoto State Government to the Realization of Objectives of Adult Education.

\begin{tabular}{|c|c|c|c|c|c|}
\hline \multirow[t]{2}{*}{$\mathbf{S} / \mathbf{N}$} & \multirow[t]{2}{*}{ Item Statement } & \multicolumn{2}{|c|}{ Agree } & \multicolumn{2}{|c|}{ Disagree } \\
\hline & & & $\%$ & f & $\%$ \\
\hline \multirow{3}{*}{$\begin{array}{l}1 . \\
2 .\end{array}$} & $\begin{array}{l}\text { The Sokoto State Government adequately provides } \\
\text { funding. }\end{array}$ & 00 & 0 & 7 & 100 \\
\hline & The Sokoto State Government adequately provides & & & & \\
\hline & instructional materials. & 121 & 32 & 256 & 68 \\
\hline 3. & $\begin{array}{l}\text { The Sokoto State Government adequately provides } \\
\text { furniture to adult education centers. }\end{array}$ & 115 & 32 & 246 & 68 \\
\hline \multirow{3}{*}{$\begin{array}{l}4 . \\
5 .\end{array}$} & The Sokoto State Government adequately provides & & & & \\
\hline & transportation facilities to adult education. & .27 & 87 & 04 & 13 \\
\hline & $\begin{array}{l}\text { The Sokoto State Government } \\
\text { pays staff and instructors' allowances regularly }\end{array}$ & 57 & 35 & 107 & 65 \\
\hline 6. & $\begin{array}{l}\text { The Sokoto State Government adequately provides } \\
\text { training opportunity for staff. }\end{array}$ & 23 & 14 & 148 & 86 \\
\hline
\end{tabular}

Funding is a pillar upon which the success or failure of implementing any form of Educational Policy like Adult Education Policy depend on. To investigate the adequacy or inadequacy of the funds provided to the State Agency for Mass Education, the State officials of the Agency were asked to state whether or not they are provided with adequate funds as required by the National Policy on Education (2004). Table 1 item 1 shows that $100 \%$ of the respondent's view that funds provided to the Agency for Mass Education by the State Governments is inadequate. This is a very serious problem, which requires quick response from the government in order to salvage Adult Education from total collapse.

Provision of instructional materials is very essential if meaningful teaching and learning activities are to take place effectively and efficiently. It is in consideration of this fact that the National Policy on Education (2004) assigned the responsibility of providing these materials to the State and the Local Governments. The researcher requests the respondents to state whether or not their centers are provided with instructional materials. The data on Table 1 item 2 above shows that $32 \%$ of the respondents responded positively to the question, while $68 \%$ responded negatively. From the majority views therefore, it could be concluded that instructional materials are not adequately provided for the effective implementation and sustenance of Adult Education in Sokoto State. 
The need for furniture for effective and successful teaching and learning activities cannot be over emphasized. This is because it brings comfort in teaching and learning which is of paramount importance to successful teaching. The officials of the State Agency for Mass Education, Local Government Adult Education officials. Adult Education Instructors and Learners were asked to state whether or not furniture are being provided in all the Adult Education Centers in the three Educational Zones in Sokoto State. Table 1 item 3 above shows that $32 \%$ of the respondents responded that furniture were provided in all centers of Adult Education in Sokoto State while $68 \%$ responded that furniture were not provided. From this data it could be concluded that though furniture were provided, but were inadequate.

Constant and regular visits to all the Adult Education Centers across the State would, to a greater extent, facilitate the efficient, effective and successful implementation of the adult education policy programmes. In. consideration to this fact, the researcher asked the State officials of the State Agency for Mass Education and Local Government Adult Education, Coordinators on the provision of transportation. The question was intended to find out whether the State Government provides transport for the Local Government Adult Education coordinators or not. Table 1 item 4 above shows that $87 \%$ of the respondents responded positively while $13 \%$ responded negatively. The data clearly shows that the majority views indicated that the government provides transport for staff of the Agency for effective Monitoring and Supervision of Adult Education Programmes in Sokoto State. Further question reveals that the State Government provides officials vehicles to the Agency while staff secured their personal loan vehicles. It was also learnt that government provides maintenance and fueling allowances for maintenance and fuelling of all official vehicles. Presently, the State Agency for Mass Education has nine motor vehicle and fourteen (14) motorcycles out of which only three (3) motor vehicles are functioning while the remaining six (6) need repairs, which could not be done as a result of financial constraints. All the fourteen (14) motorcycles are functional and in active use. Forty-six (46) additional motorcycles were also provided to the twenty three (23) Local Government Area of Sokoto State by UNICEF. This is in order to facilitate supervision of the implementation of Adult Education Programs in the State. This collaborative effort in the provision of transportation to the State Agency officials by the State Government and UNICEF is very commendable. With- this analysis, it could be concluded that the Sokoto State Government provides adequate transportation to the State Agency for Mass Education.

Provision of welfare to all categories of staff in any educational institution is necessary in order to encourage them to work harder so as to aid the successful attainment of their objectives. Though Adult Education in Sokoto State has been characterized by a number of financial constraints, staff and instructors of Adult Education need to be adequately taken care of, particularly with regards to their salaries, allowances and general welfare. On issue of salary and allowances, the staff and instructors were asked to indicate whether they are satisfied with their salary and allowances. Table 1 item 5 above indicates that $35 \%$ of the respondents 
are satisfied with their salaries and allowances while $65 \%$ that constitute the majority of the respondents responded negatively. All the staff of the State Agency including Local Government Adult Education Coordinators are permanent staff. Their salaries depend on one's grade level. As for the instructors. their allowances ranges between $\$ 500.00$ to 1. 000.00 monthly as individual Local Government Council pays different rate.

The data on table 1 item 6 above clearly indicates that $18 \%$ of the respondents are paid by the State Government while $82 \%$ are paid by the Local Government Councils. This entails that payment of staff and instructors of Adult Education in Sokoto State is shared between the State and the Local Governments. Further question reveals that Local Government Councils also assist in supervision, provision of instructional materials and training of Local Government organizers and Instructors. This is in line with the provision of the National Policy on Education (2004), which spelt out the responsibilities of the State and Local Government Councils.

The, presence or absence of staff training is one of the major factors that make or mar the implementation of all forms of policies in Nigeria generally and Sokoto State in particular.
Whatever resources and equipments are provided for the implementation of a policy, the availability of trained personnel or implementers would to a large extent determine the degree of its success. It is against this background that the researcher intended to find out whether or not the State Agency for Mass Education organizes seminars. workshops and other short courses for the staff and instructors of Adult Education in Sokoto State so as to update their knowledge and acquire modern teaching skills. Table 1 item 7 above indicated that $86 \%$ of the respondents viewed that no training is being provided for the staff and instructors of Adult Education in Sokoto State, while $14 \%$ responded positively. From the majority view therefore, it could be concluded that staff training and development is not given prior attention. This is a bad situation that requires immediate attention from the government if Adult Education implementation is to succeed in Sokoto State for the benefit of all.

\section{Problems of Adult Education Policy Implementation}

Research Question 2: What are the Problems Militating Against the Implementation of Adult Education Programs in Sokoto State?

This research question was answered and presented in table 3.

Table 2: $\quad$ Problems affecting the Implementation of Adult Education

\begin{tabular}{llcccc}
\hline S/N & \multicolumn{1}{c}{ Item Statement } & \multicolumn{2}{c}{ Agree } & \multicolumn{2}{c}{ Disagree } \\
& & f & $\%$ & f & $\%$ \\
\hline 1. & There is problem of inadequate funding & 320 & 83 & 64 & 17 \\
2. & There is problem of poor co-ordination & 332 & 86 & 52 & 14 \\
3. & There is problem of poor supervision & 300 & 78 & 84 & 22 \\
4. & There is lack of instructional malterials & 290 & 76 & 94 & 24 \\
\hline
\end{tabular}


Table 2 item 1 shows that $83 \%$ of the respondents viewed that inadequate funding is one of the major problems that militate against effective implementation of Adult Education Policy in Sokoto state while 17\% of the respondents disagree with the statement.

Table 2 item 2 on the above table indicated that $86 \%$ of the respondents agreed that there is poor coordination of Adult Education Policy Implementation in Sokoto State while $14 \%$ disagree with the statement. This clearly shows that poor coordination of adult education policy implementation militate against effective implementation of adult education policy in Sokoto state.

Table 2 item 3 on the above table indicated that $78 \%$ of the respondents agreed that there is problem of poor supervision of Adult Education programmes in Sokoto State while $22 \%$ disagreed with the position. It is therefore correct to say that poor supervision militates against effective implementation of Adult Education programme in Sokoto State

Table 2 item 4 on the above table indicated that $76 \%$ of the respondents agreed that there is lack of adequate instructional materials for the implementation of Adult Education Policy/programmes in Sokoto State while $24 \%$ disagreed with the statement. Going by the majority view, it could be concluded that lack of adequate instructional materials militates against effective and efficient implementation of Adult Education Policy in Sokoto State.

Tilble 2 item 5 on the above table also indicalled that $7.3 \%$ of the respondents agreed that lack of adequate infrastructures militates against effective implementation of Adult Education Policy in Sokoto State while $27 \%$ disagreed with the assertion. This revealed that lack of adequate infrastructures militates against effective .implementation of Adult Education Policy in Sokoto State.

\section{Conclusion}

In conclusion, this paper is on an analysis of the implementation of Adult Education Policy in Sokoto State. It investigated the efforts of the Sokoto state government in implementing the adult education policy in the state with particular reference to funding, provision of furniture, instructional materials, etc. It also investigated some of the Problems militating against effective and efficient implementation of adult education in Sokoto State and made some recommendations on how to remedy such problems.

\section{Recommendations}

For effective implementation of Adult Education Programmes in Sokoto State the following recommendations are hereby proffered:

1. The State Agency for Mass Education should be adequately funded by Sokoto State Government. This could be achieved by improving the budgetary allocation to adult education at the federal, state and local government levels.

2. Adult Education Programmes should be properly organized and coordinated by the State Agency for Mass Literacy Education all all levels. That is 
at Districts/wards, Local Governments and State levels.

3. The State Agency for Mass Education should embark on a more serious supervision and monitoring of Adult Education policy implementation in the state.

4. The State Agency for Mass Education should provide adequate instructional materials to all Adult Education Centers in the state.

5. The State Agency for Mass Education should provide adequate infrastructures at all the Adult Education learning centers in the State. This could be achieved through collaborative effort among the state, local government and non-Governmental organization.

\section{References}

Aderinoye, R. (2002): Literary Assessment Practice (LAP) in Selected Developing Countries: Nigeria Case Study, (online)

Alao, J. D. (1992): "Adult Education Practice in Nigeria: A Rear-View Mirrow Approach". Education Today. 5 (4).

Alonge, S.A. (1990): , The Role of, Government in the Provision of Adult Literacy. A paper presented at the writers workshop of committee on Blue Print on National Mass Literacy, Conference and Training Center Ogere-Nigeria

Dukku, M.G. (1999): History and Development of Adult Education in Sokoto State; Implication for current National Mass Literacy Campaign in Nigeria. A seminar paper presented at University Staff Seminar Series on Thursday $8^{\text {th }}$ April, 1999 at Usmanu Danfodiyo University Sokoto.

Dukku, M.G (2003): "Introductory Notes on Adult Literacy". In Junaid, M.I.; Salawu A.A.; Maitafsir, M. G. (eds) Readings in Education, II.

Dukku, M.G. (2002): "Meaning, Scope and Purpose of Adult Education" in Adeyanju, T.K and Dukku M.G. Revitalizing Education in Northern States; Kaduna: Arewa House, ABU

Federal Republic of Nigeria (2004): National Policy on Education. Lagos: NERDC Press

Federal Government of Nigeria (1990): Official Gazette. Lagos: Federal Government Press.

Indabawa, S. A. (1991): Themes in Adult and Non-Formal Education. Ikeja-Lagos: Test and Leisure Publishers.

Morgan; D. W. and Kreycie (1971): Determining Sample Size for Research Activities. Unconn. Edu/wwwdeslsiegle.com

Omolewa, M. (1985): Adult Education Practice in Nigeria. Ibadan: Evans Brothers (Nigeria Publishers) Limited.

Sokoto State Government (2003): Great Leap Forward: Five Years of His Excellency Alh. (Dr.) Attahiru Dalhatu Bafarawa. Deputy Governor's Office: Sokoto

Rashid, (2002): Literary Assessment Practices (LAP) in selected Developing Countries, Nigeria Case study; Discussion Documented prepared for ILI UNESCO LAP $2^{\text {nd }}$ Expert meeting, UNESCO Paris.

Tahir, G. (1986): "Adult Education and the New National Policy on Education in Nigeria: Problems and Prospects". Joumal of Indian Education. 
Udoh, O. and Akpa, O. (2001)

Educational Administration in

Nigeria: Theory and Practice.

Nigeria: Ichejum Publishers. 